\title{
Correction to: Epidemiological and entomological studies of malaria transmission in Tibati, Adamawa region of Cameroon 6 years following the introduction of long-lasting insecticide nets
}

Lionel Brice Feufack-Donfack ${ }^{1,2+}$, Elangwe Milo Sarah-Matio ${ }^{1,3+}$, Luc Marcel Abate ${ }^{3}$, Aline Gaelle Bouopda Tuedom ${ }^{1,8}$, Albert Ngano Bayibéki ${ }^{4}$, Christelle Mafo Ngou ${ }^{1,3}$, Jean-Claude Toto ${ }^{5}$, Maurice Marcel Sandeu ${ }^{6,7}$, Carole Else Eboumbou Moukoko 1,8, Lawrence Ayong ${ }^{1}$, Parfait Awono-Ambene ${ }^{5}$, Isabelle Morlais ${ }^{1,3}$ and Sandrine Eveline Nsango ${ }^{1,8^{*}}$

\section{Correction to: Parasites Vectors 14:247 (2021)} https://doi.org/10.1186/s13071-021-04745-y Following publication of the original article [1], it came to our attention that the article had published with an incorrect file for the Graphical abstract; the article had published with a screenshot of its Abstract as the Graphical abstract.

The original article has since been updated and the correct Graphical abstract may be found in this correction for reference.

The original article can be found online at https://doi.org/10.1186/s13071021-04745-y.

*Correspondence: nsango2013@yahoo.fr; nsango@pasteur-yaounde.org †Lionel Brice Feufack-Donfack and Elangwe Milo Sarah-Matio contributed equally to this work

1 Service de Paludisme du Centre Pasteur Cameroun, BP 1274, Yaounde, Cameroon

Full list of author information is available at the end of the article

(c) The Author(s) 2021. Open Access This article is licensed under a Creative Commons Attribution 4.0 International License, which permits use, sharing, adaptation, distribution and reproduction in any medium or format, as long as you give appropriate credit to the original author(s) and the source, provide a link to the Creative Commons licence, and indicate if changes were made. The images or other third party material in this article are included in the article's Creative Commons licence, unless indicated otherwise in a credit line to the material. If material is not included in the article's Creative Commons licence and your intended use is not permitted by statutory regulation or exceeds the permitted use, you will need to obtain permission directly from the copyright holder. To view a copy of this licence, visit http://creativecommons.org/licenses/by/4.0/. The Creative Commons Public Domain Dedication waiver (http://creativeco mmons.org/publicdomain/zero/1.0/) applies to the data made available in this article, unless otherwise stated in a credit line to the data. 


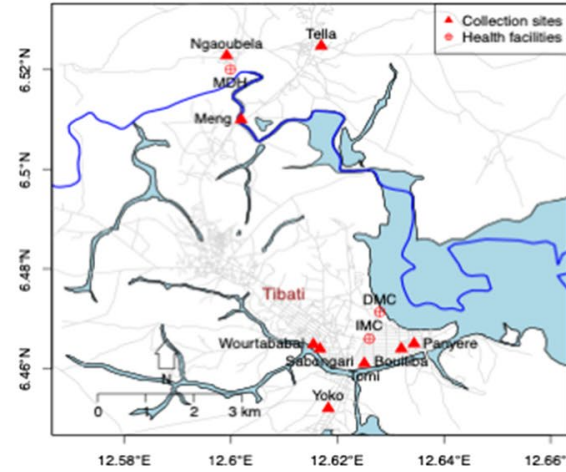

\section{Author details}

'Service de Paludisme du Centre Pasteur Cameroun, BP 1274, Yaounde, Cameroon. ${ }^{2}$ CNRS UPR 9022, Inserm U 963, Université de Strasbourg, 2, allée Konrad Roentgen, 67084 Strasbourg Cedex, France. ${ }^{3}$ UMR MIVEGEC, Institut de Recherche Pour Le Développement, IRD, CNRS, Université de Montpellier, 911 avenue Agropolis, 34394 Montpellier, France. ${ }^{4}$ Université Catholique D'Afrique Centrale, Yaoundé-Campus Messa, BP 1110, Yaounde, Cameroon. ${ }^{5}$ Laboratoire de Recherche Sur Le Paludisme, Organisation de Coordination Pour La Lutte Contre Les Endémies en Afrique Centrale, BP 288, Yaounde, Cameroon. ${ }^{6}$ Department of Medical Entomology, Centre for Research in Infectious Diseases, Yaounde 13591, Cameroon. ' Department of Microbiology and Infectious Diseases, School of Veterinary Medicine and Sciences, University of Ngaoundere, PO Box 454, Ngaoundere, Cameroon. ${ }^{8}$ Faculté de Médecine Et Des Sciences Pharmaceutiques de L'Université de Douala (FMSP-UD), BP 2701, Douala, Cameroon.

Published online: 04 October 2021

\section{Reference}

1. Feufack-Donfack LB, Sarah-Matio EM, Abate LM, Tuedom AGB, Bayibéki AN, Ngou CM, Toto JC, Sandeu MM, Moukoko CEE, Ayong L, AwonoAmbene P, Morlais I, Nsango SE. Epidemiological and entomological studies of malaria transmission in Tibati, Adamawa region of Cameroon 6 years following the introduction of long-lasting insecticide nets. Parasites Vectors. 2021;14:247. https://doi.org/10.1186/s13071-021-04745-y.

\section{Publisher's Note}

Springer Nature remains neutral with regard to jurisdictional claims in published maps and institutional affiliations. 